S. Laleta, D. Senčur Peček*

\title{
ATIPIČNI RAD - IZAZOVI ZAŠTITE OD PSIHOSOCIJALNIH RIZIKA I STRESA NA RADU I U VEZI S RADOM ${ }^{* *}$
}

UDK 331.45:159.944

PRIMLJENO: 9.3.2017.

PRIHVAĆENO: 3.7 .2017

SAŽETAK: U radu se analiziraju atipični oblici zapošljavanja i organizacije rada, s posebnim težištem na uvjete rada radnika te njihovu zaštitu od psihosocijalnih rizika $i$ stresa na radu, $u$ svjetlu obveza država članica EU-a i europskih socijalnih partnera u ovome području zaštite sigurnosti i zdravlja na radu. Autorice daju komparativnopravnu analizu te iznose prijedloge de lege ferenda.

Ključne riječi: atipični rad, stres na radu i u vezi s radom, Okvirni sporazum, hrvatsko pravo, slovensko pravo, usporedno pravo

\section{UVOD}

Mnoštvo je dokaza o negativnim učincima koje na zdravlje i sigurnost radnika ima radno okruženje koje pred njega postavlja prevelike zahtjeve (Irastorza, 2016: 39). Podaci pokazuju da $25 \%$ svih radnika u Europi osjeća stres na radu stalno ili veći dio radnog vremena, a sličan broj navodi da rad utječe negativno na njihovo zdravlje (Eurofound and EU-OSHA, 2014: 6d). U Hrvatskoj, također, raste broj oboljelih od bolesti, stresa i depresije u vezi s radom (Vaughan-Whitehead, 2015: 17). To vrijedi i za Sloveniju jer istraživanja pokazuju da radnici pate od nervoze, nesanice i drugih zdravstvenih poteškoća povezanih sa stresom (Kanjuo Mrčela, Ignjatovič, 2012: 17, 18). Psihosocijalni rizici i stres na radu predstavljaju problem koji se pojačava posljednjih desetak

*Izv. prof. dr. sc. Sandra Laleta, (sandra.laleta@pravri.hr), Pravni fakultet Sveučilišta u Rijeci, Hahlić 6, 51000 Rijeka, Hrvatska, izv. prof. dr. sc. Darja Senčur Peček, (darja.sencur-pecek@um.si), Pravna fakulteta Univerze v Mariboru, Mladinska ulica 9, 2000 Maribor, Slovenija.

** Ovaj rad financirala je Hrvatska zaklada za znanost projektom UIP-2014-09-9377 Fleksigurnost i novi oblici rada (izazovi modernizacije hrvatskog radnog prava). godina povezano s gospodarskom krizom, globalizacijom, ali i korištenjem informacijske i komunikacijske tehnologije, rastom uslužnog sektora, novih oblika upravljanja ljudskim potencijalima (Cox, Fletcher, 2014: 8d). Kriza utječe na promjenu sadržaja radnog mjesta i s time povezane psihosocijalne rizike (Eurofound, 2013: 37). Potreba stvaranja novih radnih mjesta kako bi se odgovorilo na rastuću nezaposlenost mijenja svijet rada koji sve više obilježavaju fleksibilni, atipični, novi oblici zapošljavanja i organizacije rada koji su sve stresniji za radnike (ILO, 2006: 33d). To predstavlja veliki izazov za oblikovanje i regulativu zaštite zdravlja i sigurnosti na radu. Utjecaj promjena organizacije rada na zdravlje radnika prepoznala je i Europska komisija koja ističe važnost razvijanja i promicanja dobrih praksi u sprečavanju problema mentalnog zdravlja na radu u vezi sa starenjem radne snage, pojavom novih rizika te prevencijom bolesti na radu i u vezi s radom općenito ( $E C$, 2014: 17).

Stres na radu i u vezi s radom predstavlja "stanje praćeno fizičkim, psihološkim ili društvenim poteškoćama ili disfunkcijama koje kod pojedinca izazivaju osjećaj nesposobnosti udovoljavanja 
zahtjevima ili očekivanjima koja su pred njega postavljena. Stres na radu nije bolest, no dulje izlaganje stresu može smanjiti učinkovitost radnika te uzrokovati loše zdravlje" (Okvirni sporazum o stresu na radu (2004.), toč. 3., dalje u tekstu: OS). Riječ je o negativnom iskustvu koje nastaje kao rezultat izloženosti lošim uvjetima rada (psihosocijalnim i/ili fizičkim); (Leka et al., 2015; WHO, 2008: 1). Rezultat je različitih čimbenika, a usko je povezan s izlaganjem psihosocijalnim rizicima koji su njegov uzrok, a s kojima se često pogrešno poistovjećuje (Leka et al., 2015: 63d). Psihosocijalni rizici jesu "takvi aspekti oblikovanja rada, organizacije i upravljanja radom te njihov socijalni i okolišni kontekst koji mogu uzrokovati psihološku, socijalnu i fizičku povredu" (Cox, Griffiths, 1996.). Uključuju pitanja poput zahtjeva posla, dostupnosti organizacijske potpore, nagrada i odnosa među osobljem, kao i zlostavljanja i bulinga na radnom mjestu.

Ovi problemi prepoznati su na razini Europske unije te danas postoji široki pravni i institucionalni okvir. Sve države članice obvezuju odredbe direktiva koje sadrže minimalne standarde zaštite. To je opća pravna osnova uređenja zaštite zdravlja i sigurnosti na radu, tzv. "čvrsto" pravo (hard law), EU stečevina (acquis) o zdravlju i sigurnosti na radu (Irastorza et al., 2016: 39; EC, 2011: 9). Države članice implementirale su u svoje zakonodavstvo Okvirnu direktivu 89/391/EEZ o uvođenju mjera za poticanje poboljšanja sigurnosti i zdravlja radnika na radu koja obuhvaća sve oblike rizika za radnikovo zdravlje i sigurnost te se odnosi i na organizaciju rada, uključujući i psihosocijalne rizike. Poslodavac je obvezan zajamčiti sigurnost i zdravlje radnika „u svakom aspektu koji se odnosi na rad". Dužan je procijeniti rizike koji se ne mogu izbjeći te imati procjenu rizika sigurnosti i zdravlja na radu, uključujući one s kojima su suočene skupine radnika izložene posebnim rizicima. Posebno osjetljive rizične skupine moraju biti zaštićene od opasnosti koje ih posebno ugrožavaju. Preventivne mjere i radne i proizvodne metode moraju biti uključene u sve aktivnosti poduzeća i/ili pogona i na svim razinama. Okvirna direktiva zato predstavlja pravnu osnovu za uređivanje obveza povezanih sa psihosocijalnim rizicima (Šokčević, 2014: 223), iako se "psihosocijalni rizici“, "mentalno zdravlje“ i "stres na radu" u njoj izričito ne spominju zbog njezine opće naravi. To je potvrđeno i u praksi Suda Europske unije u predmetu European Com- mission v. Italy (C-49/00) u kojem je Sud zauzeo stajalište da "to proizlazi iz svrhe direktive, koja se u skladu s 15 . recitalom primjenjuje na sve rizike, te iz formulacije čl. 6(3)(a) da su poslodavci obvezni ocijeniti sve rizike za sigurnost i zdravlje radnika. Također valja istaknuti da profesionalni rizici koje poslodavci moraju ocijeniti nisu utvrđeni jednom zauvijek, već se kontinuirano mijenjaju ovisno, posebice, o postupnom razvoju uvjeta rada i znanstvenom istraživanju takvih rizika" (toč. 12 i 13). Ovu obvezu poslodavaca treba istaknuti u kontekstu specifičnih uvjeta rada i rizika kojima su izloženi radnici koji obavljaju neki "atipični rad“, a koji se analiziraju u ovom radu. Zbog posebnosti uvjeta rada za te su skupine radnika važne i posebne direktive donesene na temelju čl. 16. Okvirne direktive koje dodatno uređuju neke specifične rizike i radna mjesta, a odnose se na organizaciju radnog vremena, rad sa zaslonima, unapređenje sigurnosti i zdravlja na radu trudnih radnica i radnica koje su rodile i dojilja, sprečavanje ubodnih ozljeda u bolnicama, kao i rad na određeno vrijeme i privremeni rad. Na koncu, može se zaključiti da na razini EU-a postoji široki, za države članice, obvezujući pravni okvir za borbu protiv psihosocijalnih rizika i stresa na radu (EC, 2011: 10).

No, u području psihosocijalnih rizika, kao segmenta socijalnih politika općenito, posebnu, relativno novu ulogu ima europski socijalni dijalog (Ertel et al., 2010.), kao "novi vladavinski model“ (new mode of governance); (Laleta, Bodiroga-Vukobrat, 2016: 36d). Europski socijalni partneri donijeli su 2004. godine, nakon niza aktivnosti, Okvirni sporazum o stresu na radu i u vezi s radom kojim se nastoji podići svjesnost te upoznati poslodavce, radnike i njihove predstavnike s ovim problemom, kako bi mogli uočiti znakove stresa na radu. Cilj je stvoriti normativni okvir koji će u tome pomoći te omogućiti sprečavanje ili rješavanje problema stresa u vezi s radom, kako pomoću inicijative svih socijalnih partnera tako i drugih dionika odgovornih za razvoj politika i aktivnosti. Sporazum sadrži primjeričnu listu mogućih čimbenika stresa kao i određene kolektivne i pojedinačne mjere koje se mogu poduzeti (Laleta, 2014., 2016.). Odnosi se na sva radna mjesta i sve radnike, bez obzira na veličinu poduzeća, područje aktivnosti ili vrstu ugovora o radu ili odnosa zaposlenja, iako se ističe da na svim radnim mjestima i svi radnici nisu nužno ugroženi stresom na radu i u vezi s radom. 
Okvirni sporazum nadopunjuje Okvirnu direktivu koja neizravno, ali obvezujuće, obuhvaća psihosocijalne rizike. Sporazum je soft law instrument, autonomni sporazum koji je obvezujući za njegove potpisnike i njihove članove. Obilježje fleksibilnosti daje mogućnost izbora metode implementacije, ali ne i izbora hoće li ga ili ne potpisnici implementirati. Analiza pokazuje da se u implementaciji Sporazuma koriste četiri temeljne skupine instrumenata: nacionalni kolektivni ugovori; opći sporazumi, preporuke ili smjernice koje donose socijalni partneri; zajedničke deklaracije socijalnih partnera te zakonodavstvo. Riječ je o gruboj podjeli, a uz navedene instrumente primjenjuju se i drugi te provode različite aktivnosti koje olakšavaju implementaciju (EC, 2011: 14-21). lako su implementacijom OS-a postignuti značajni rezultati u uvođenju minimalne razine zaštite od stresa na radu, čini se da na putu stoje mnogi izazovi. To potvrđuju i podaci provedenih istraživanja detaljnije prikazani u sljedećem poglavlju. Svi poslodavci složit će se s tezom da je za uspjeh i kompetitivnost važno dobro upravljanje poduzećem i rizicima poslovanja. No, kada je riječ o upravljanju psihosocijalnim rizicima, poslodavci ga još uvijek ne prepoznaju kao prioritetni problem, možda i zato što su troškovi koji nastaju kao rezultat stresa i s time povezanih zdravstvenih problema nevidljivi neizravni troškovi (Leka, 2015., Ertel et al., 2010: 175). Zato se s pravom postavlja pitanje jesu li instrumenti i pristup ovom problemu, dakle postojeći pravni okvir i soft law pristup kroz socijalni dijalog prikladni i učinkoviti (Ertel et al., 2010: 170).

U nastavku rada najprije se analiziraju specifičnosti i problemi u implementaciji Sporazuma. Zatim se razrađuju atipični oblici rada te pretpostavke učinkovite zaštite ove skupine radnika od psihosocijalnih rizika i stresa na radu.

\section{IMPLEMENTACIJA OKVIRNOG SPORAZUMA}

\section{Općenito}

Sporazum je prvi korak prema stvaranju prikladnijih pravila i mehanizama za prepoznavanje, sprečavanje i otklanjanje problema stresa na radu. Mjere njegove implementacije obuhvatile su najprije fino usklađivanje s postojećom nacionalnom regulativom država članica EU-a, potom podizanje svjesnosti o sporazumu na nacionalnoj razini, razini sektora i poduzeća te na koncu donošenje konkretnih mjera i alata za borbu protiv stresa na radu. Sporazum se koristi kao sredstvo za podizanje svjesnosti o problemu, ali i za unapređenje socijalnog dijaloga u ovom području. Socijalni partneri poduzeli su najviše aktivnosti u onim državama EU-a u kojima je već postojala visoka svjesnost o stresu na radu (Finska, Nizozemska, Švedska, Danska, Francuska i UK); (ESP, 2008: 6d).

U implementaciji Sporazuma posebnu važnost ima socijalni dijalog, kao ključni čimbenik unapređenja uvjeta rada radnika. Njegova uloga ovisi o posebnostima tradicije i kulture individualnih i kolektivnih radnih odnosa, organizaciji tržišta rada, radnom zakonodavstvu, strukturi dijaloga te važnosti koja se psihosocijalnim rizicima pridaje u pojedinoj državi. Socijalni dijalog na razini sektora i poduzeća najviše pridonosi učinkovitom upravljanju psihosocijalnim rizicima i stresom na radu. Nacionalni granski kolektivni ugovori koji uređuju prava i obveze stranaka potpisnica zaključeni su u Belgiji, Danskoj (za javni sektor), Francuskoj, Italiji, Rumunjskoj, Grčkoj. Do proširenja primjene kolektivnih ugovora došlo je u Belgiji, Francuskoj i Rumunjskoj. Puno se češće sklapaju opći sporazumi te donose zajedničke preporuke i smjernice za djelovanje članova organizacija radnika i poslodavaca, primjerice smjernice za pregovaranje i druge zajedničke aktivnosti na razini djelatnosti i poduzeća (Finska i Švedska), praćeno i djelovanjem tripartitnog savjeta za socijalni dijalog (Nizozemska, Luksemburg). U Irskoj, Austriji i Ujedinjenom Kraljevstvu socijalni partneri na temelju sporazuma unaprijedili su ranije stvoren praktični alat za borbu protiv stresa na razini organizacije. Deklaracije kojima socijalni partneri prihvaćaju obvezu implementacije Okvirnog sporazuma često ostaju na razini puke forme (Eurofound, EU-OSHA, 2014: 57d).

Zakonodavstvo se koristi kao glavni ili jedan od instrumenata implementacije Okvirnog sporazuma. Pritom inicijativa može doći od socijalnih partnera i/ili nakon savjetovanja s njima (npr. u Latviji, Mađarskoj i Slovačkoj). U nekim državama temelj za implementaciju bili su nacionalni 
kolektivni ugovori pa su, primjerice u Belgiji oni postali dio zakonodavstva, dok je u Italiji međukonfederalni sporazum potaknuo reviziju zakonodavstva o zaštiti na radu.

U određenom broju zakonodavstava psihosocijalni rizici, stres na radu ili mentalno zdravlje ne spominju se izričito, dok se druga njima bave manje ili više detaljno, no vrlo rijetko tako sveobuhvatno kao što je to učinjeno u Okvirnom sporazumu. U dijelu država poslodavci su zakonski obvezni djelovati preventivno, procijeniti i poduzimati mjere sprečavanja ili rješavanja psiholoških i socijalnih čimbenika, psihosocijalnih rizika, mentalnog opterećenja i drugih aspekata u vezi sa stresom koji utječu na zdravlje radnika. U drugima, pak, zakonodavstvo je preciznije te se definiraju ili primjerično određuju rizici i područje djelovanja (EC, 2011: 23d). Stres na radu i u vezi s radom, buling i zlostavljanje na radnom mjestu ili psihosocijalni rizici izričito su uređeni zakonodavstvom u Belgiji, Češkoj, Italiji, Njemačkoj, Švedskoj. Ipak, samo nekoliko država uvrstilo je bolesti uzrokovane stresom na radu u službenu listu profesionalnih bolesti (Leka et al., 2015a: 4).

Okvirni sporazum implementiran je u hrvatskom pravu kroz zakonodavstvo o zaštiti na radu. lako se u literaturi to ističe kao napredno rješenje (Eurofound, 2015: 75, 82), sadašnje normativno uređenje nije učinkovito jamstvo zaštite radnika jer obveza poslodavca iz Zakona o zaštiti na radu, iz 2014. godine, brinuti o stresu na radu te poduzimati mjere za prevenciju stresa, odnosno otklanjanje ili ublažavanje njegovih posljedica nije popraćena sankcijama za kršenje odredbi odnosno odgovornošću poslodavca (Potočnjak, 2014., Laleta, 2014.).

U Sloveniji su socijalni partneri i Vlada socijalnim sporazumom za 2007.-2009. godinu dogovorili sklapanje posebnog tripartitnog sporazuma o upravljanju stresom. Imenovana je i posebna komisija pri Ekonomsko-socijalnom vijeću koja je trebala pripremiti prijedlog sporazuma. No, do potpisivanja sporazuma nije došlo zbog protivljenja, prije svega, organizacija poslodavaca koje su isticale da stres na radu i u vezi s radom nije na odgovarajući način definiran (na način da se razlikuje od stresa koji nije povezan s radom), zbog čega su lako moguće zloporabe. Osim toga, izrazile su bojazan da bi obveza upravljanja stresom na radu i u vezi s radom, kao dio upravljanja rizicima općenito, bila dodatni financijski teret za poslodavce (EC, 2011: 74). lako nije potpisan poseban sporazum, europski Okvirni sporazum primjenjuje se na temelju postojećeg slovenskog zakonodavstva, te provođenjem odgovarajućih aktivnosti (Kanjuo Mrčela, Ignjatović, 2012: 8). Zakon o sigurnosti i zdravlju na radu (Uradni list RS (UL), br. 43/2011; dalje u tekstu: ZVZD-1) ne spominje izričito stres na radnom mjestu, no neke odredbe posredno se odnose na čimbenike stresa ili spominju psihosocijalne rizike. Jedno od temeljnih načela koje poslodavac mora poštovati pri provođenju mjera za zaštitu sigurnosti i zdravlja na radu jest $\mathrm{i}$ "razvijanje cjelovite politike zaštite, što uključuje tehnologiju, organizaciju rada, uvjete rada, međuljudske odnose te čimbenike radnog okoliša" (čl. 9. ZVZD-1). U čl. 23. utvrđena je obveza poslodavca da provodi mjere za sprečavanje i uklanjanje slučajeva nasilja, mobinga, uznemiravanja te drugih psihosocijalnih rizika na radnome mjestu koji mogu ugroziti zdravlje radnika (za slučaj kršenja obveze predviđena je prekršajna odgovornost poslodavca, u čl. 76., st. 1., toč. 16.). Stručnjak zaštite na radu dužan je, među ostalim, usklađivati mjere za sprečavanje psihosocijalnih rizika (čl. 29., st. 1.). Za uklanjanje čimbenika stresa na radnom mjestu od posebne su važnosti zakonom utvrđene obveze poslodavca u vezi s planiranjem i provođenjem unapređenja zdravlja na radnom mjestu (čl. 6. i 32. ZVZD-1-a). Riječ je o "sustavnim ciljanim aktivnostima i mjerama koje poslodavac provodi u svrhu očuvanja i jačanja fizičkog i mentalnog zdravlja" (čl. 3., toč. 9 ZVZD-1). Konkretno, to su mjere (primjerice one povezane s organizacijom rada, za jačanje mentalnog zdravlja i dobrobiti radnika itd.) utvrđene u Smjernicama za unapređenje zdravlja na radnom mjestu Ministarstva zdravlja (Smernice, 2015: 7, 8). Poslodavac mora u izjavi o zaštiti s procjenom rizika planirati i urediti unapređenje zdravlja na radnom mjestu, osigurati za to potrebna sredstva te utvrditi način provođenja. Za kršenje obveza utvrđena je prekršajna odgovornost (čl. 76., toč. 27. ZVZD-1). Nadzor nad ispunjavanjem zakonskih obveza provodi inspekcija rada koja je tijelo nadležno za prekršaje.

Prema rezultatima istraživanja učinkovite metode implementacije Okvirnog sporazuma jesu 
one na razini poduzeća, posebno srednjih i malih. U cilju širenja dobrih praksi, posebice za tu skupinu poduzeća, u nekim državama razvijene su posebne metode, alati i vodiči (UK, Italija, Irska, Nizozemska). Primjerice, u Ujedinjenom Kraljevstvu i Italiji uvedeni su Standardi za upravljanje stresom na radu. Alate kreiraju i organizacije koje se bave uvjetima rada, npr. Europska agencija za sigurnost i zdravlje na radu. Ključni dionici u ovom području jesu inspektorati rada i službe za zaštitu zdravlja radnika. Inspektorat za rad u Sloveniji ima na svojoj mrežnoj stranici posebnu rubriku o psihosocijalnim čimbenicima rizika na radnom mjestu koja sadrži sve informacije, preporuke i e-alate za potporu unapređenja zdravlja zaposlenih, a izradio je i poseban dokument o unapređenju zdravlja na radnom mjestu. No, u mnogim državama deregulacija kao i smanjenje financijskih sredstava u vremenima krize umanjuje ulogu inspektorata rada. Spomenuto je da poslodavci ne prepoznaju važnost upravljanja psihosocijalnim rizicima, a isto vrijedi i za kreatore politika. $U$ literaturi se upozorava na važnost upravljanja psihosocijalnim rizicima ne samo na organizacijskoj razini, nego i na makro (državnoj) razini. Kriza i mjere štednje utječu na nezaposlenost te uzrokuju pogoršanje zdravlja radnika. Istraživanja pokazuju da je fizičko i mentalno zdravlje osoba koje su izložene najlošijem psihosocijalnom radnom okruženju lošije nego kod nezaposlenih osoba (Leka, 2015: 61d).

\section{Problemi u implementaciji i mogući odgovori}

U većini država članica implementacija Sporazuma predstavljala je značajan korak naprijed i dodanu vrijednost, iako su identificirani nedostaci u opsegu i učincima mjera te nepostojanje cjelovitog okvira aktivnosti. Ipak, socijalni partneri u mnogim državama nisu izvijestili o implementaciji Sporazuma (lavicoli et al., 2014: 864). Uređivanje odnosno upravljanje psihosocijalnim rizicima i stresom na radu jest složeno. Prema podacima iz istraživanja ESENER, koje je obuhvatilo oko 28.000 poduzeća iz 31 europske države, čak oko $40 \%$ ispitanih (menadžera) poslodavaca ocjenjuje da je ovim rizicima mnogo teže upravljati nego onim tradicionalnim, tek polovica ih informira radnike o psihosocijalnim rizicima i njihovim učincima na zdravlje i sigurnost, a manje od trećine primjenjuje odgovarajući postupak zaštite od stresa na radu. Kao glavni čimbenici za takvo stanje ističu se osjetljivost ovog pitanja, nepostojanje svjesnosti o problemu, nedostatak sredstava, osposobljavanja i informacija te prikladnih i učinkovitih alata, kao i podrške, vođenja i stručnosti (Irastorza, 2016: 40). Okvirni sporazum je općenit instrument, a ne vodič za oblikovanje, primjenu i održavanje programa upravljanja psihosocijalnim rizicima na razini poduzeća (lavicoli et al., 2014: 857-858). U literaturi se zato s pravom raspravlja o nedovoljnoj jasnoći regulatornog okvira te s time povezanim vodičima o mentalnom zdravlju na radu i upravljanju psihosocijalnim rizicima (Leka et al., 2015a: 3).

Među različitim sudionicima u europskim državama, prije svega sindikatima i organizacijama poslodavaca, postoje velike razlike u percepciji problema mentalnog zdravlja na radu, odnosno prioriteta pojedinih rizika i interesa. To je važna prepreka učinkovitoj implementaciji Okvirnog sporazuma. Zato je bitno ostvariti kvalitetan socijalni dijalog o ovom pitanju (Leka et al., 2015a: 3). Prema stajalištu europskih socijalnih partnera, pored kvalitete kolektivnih radnih odnosa, izazovi za uspješnu implementaciju jesu i: definicija stresa na radu i razgraničenje od drugih vrsta stresa te svjesnost o ovom problemu; jačanje regulatornog nacionalnog okvira pod utjecajem odredbi Sporazuma; važnost međusobnog razumijevanja i aktivnosti dionika; uloga tijela javne vlasti u uređivanju pitanja zdravlja i sigurnosti na radu; potreba kontinuiranog napretka u implementaciji europskih autonomnih sporazuma (EC, 2011: 27-30).

Kada je riječ o implementaciji Sporazuma na razini pojedine djelatnosti ili organizacije, za sada ona nije sustavna. Može se zaključiti da upravo zbog svoje autonomne naravi Okvirni sporazum ostaje tek okvir koji ne može jamčiti jednake rezultate, obvezujući status i punu primjenu u svim državama, odnosno minimalne radne standarde ili temeljna socijalna prava (EC, 2011: 24). Prikladnost i učinkovitost sporazuma koji je autonoman ili dobrovoljan propituje se u kontekstu kvalitete europskog socijalnog dijaloga u području psihosocijalnih rizika (Branch, 2005.). Neki autori pozivaju na fokusirane aktivnosti na europskoj razini kako bi se harmonizirala stajališta najvažnijih dionika 
o pitanjima stresa na radu i psihosocijalnih rizika (Ertel et al., 2010.). Traži se kritička procjena svega što je do sada učinjeno u vezi sa psihosocijalnim rizicima i stresom na radu, kako bi se razvio pristup na EU razini koji bi omogućio fleksibilnost na nacionalnoj razini, s jedne, te određenu razinu „,benchmarkinga" među državama, u smislu primjene dobre prakse i relevantnih podataka, s druge strane (lavicoli et al., 2014.).

\section{ATIPIČNI I NOVI OBLICI ZAPOŠLJAVANJA I ORGANIZACIJE RADA}

\section{Standardni radni odnos i atipični rad}

Atipični oblici zapošljavanja utječu na promjenu paradigme standardnog radnog odnosa koji se najjednostavnije može definirati kao radni odnos na neodređeno vrijeme s punim radnim vremenom (Keller, Seifert, 1993.). Standardni radni odnos vezuje se s visokom razinom (zakonske) zaštite zaposlenja (employment protection (legislation)). Shvaćena kao odgovarajuća zaštita radnika od arbitrarnih odluka poslodavca (menadžmenta) već se dugo smatra temeljnim stupom radnoga prava. Ona danas obuhvaća značajno šire područje zaštite od onog izvornog, pa uz mjere zaštite zdravlja i sigurnosti na radu te radno vrijeme, obuhvaća i zaštitu od diskriminacije te posebice uređenje nezakonitog prestanka ugovora o radu. Posebno je važno pitanje koje osobe ulaze u krug radnika (posloprimaca) jer se samo na njih primjenjuje radno zakonodavstvo odnosno socijalnozaštitno zakonodavstvo (Deakin, 2006., Goldin, 2006., Senčur Peček, 2016.). Danas se visoka zaštita zaposlenja smatra uzrokom nezaposlenosti, iako ta teza nije dokazana. Zakonodavstvo koje uređuje zaštitu zaposlenja pred mnogim je izazovima koji su prije svega rezultat porasta atipičnog rada ( $R O-$ gowski, 2013: 87d).

Atipični oblici rada često se povezuju s prekarnim radom čije je obilježje smanjena zaštita zaposlenja radnika. Prekarni rad rezultat je politika fleksibilizacije i deregulacije tržišta rada te liberalizacije radnoga prava koji, prema mišljenju nekih političkih ekonomista, mogu voditi stvaranju velike skupine radnika u nesigurnom zaposlenju, odnosno nove društvene klase (Rogowski, 2013: 92-93), "prekarijata” (Standing, 2011.).
Danas je na djelu povijesna eskalacija prekarnog rada (ILO, 2012: 15). Obilježje "prekarnosti“ znači socijalnu i ekonomsku ranjivost radnika, nestabilnost, (objektivnu i subjektivnu) „nesigurnost" (Bodiroga-Vukobrat et al., 2016: 406d). No, u nekim slučajevima atipični rad jest dobrovoljni izbor radnika, primjerice rad u nepunom radnom vremenu, pa se ne može govoriti o prekarnosti takvog rada (Bilić et al., 2015.). U svjetlu rasprava o atipičnom radu standardni radni odnos se redefinira kako bi se odgovorilo potrebama fleksibilnosti (Bosch, 2004.). Diskrecijske ovlasti poslodavca snažno su ojačale kod onih ugovora o radu koje obilježava neodređenost nekih temeljnih elemenata kao što je trajanje radnog vremena, razlikovanje razdoblja u kojima je radnik radio ili nije radio, kao i obveza informiranja radnika u nekom razumnom vremenu o promjenama uvjeta rada. Mogu se pronaći kod ugovora na poziv, ugovora na nula sati i nekih oblika rada s nepunim radnim vremenom (Schiarra, 2006: 263).

Fleksibilni prekarni oblici rada uzrokuju štetne posljedice za zdravlje i blagostanje radnika. Povezani su s općenito lošim, rizičnim uvjetima rada, psihosocijalnim rizicima i stresom na radu i u vezi $\mathrm{s}$ radom, preopterećenosti poslom, nerazmjerno dugim vremenom putovanja na dva ili više radnih mjesta u zemljopisno udaljena mjesta rada. Radnici često imaju slabije mogućnosti usavršavanja i napredovanja, manje su upoznati s pravilima zaštite na radu, a inspekcije manje nadziru primjenu mjera zaštite na radu. $\mathrm{S}$ obzirom da ih najčešće prati nesigurnost zaposlenja, slaba primanja, ali i niža razina socijalne zaštite, kao i nedobrovoljan izbor takvog oblika rada, često su sami po sebi uzrok slabijeg fizičkog i mentalnog zdravlja radnika (ILO, 2012: 37-38; Barrett, Sargeant, 2016: 3-4). Često je riječ o privremenom radu, u (nedobrovoljnom) nepunom radnom vremenu, predugom ili nepredvidivom radnom vremenu, o nepredvidivoj količini posla, sa češćim ozljedama na radu. Ako je radno vrijeme zbog recesije produljeno ili skraćeno, to može izazvati stres. $U$ ovom posljednjem slučaju radnicima se smanjuju prihodi, a posljedica je siromaštvo (in-work-poverty); (ILO, 2013: 9d). O ozbiljnosti problema svjedoči podatak da se s ovim problemima suočava četvrtina stanovništva EU-a (Parent-Thirion et al., 2012: 128d). Nesigurnošću radnog mjesta kao jednim od najvažnijih psihosocijalnih rizika 
današnjice trebala bi se baviti ne samo politika zaštite na radu, već ekonomska politika i tržište rada (Cox, Fletcher, 2014: 10d).

Valja istaknuti da se radni odnos na određeno vrijeme, rad u nepunom radnom vremenu i rad putem agencija za privremeno zapošljavanje danas već mogu smatrati "klasičnim", "tradicionalnim" atipičnim oblicima rada. Među atipične radnike mogu se ubrojiti i pripravnici i naučnici, kao i "ovisni“ nezavisni ugovaratelji (samozaposlene osobe); (Stone, 2006: 170). U takvom širokom spektru atipičnog rada mogu se kao segment izdvojiti „novi oblici rada" (new forms of employment). Oni su rezultat društvenih i ekonomskih promjena koje uključuju potrebu veće fleksibilnosti za poslodavce i radnike, rašireno korištenje informacijsko-komunikacijskih tehnologija (ICT) i važnost određenih poslovnih aktivnosti i zanimanja. Zbog svojih obilježja zanimljivi su za poslodavce, ali i radnike. Njihov utjecaj na stvaranje novih radnih mjesta, integraciju tržišta rada i uvjete rada još uvijek nije dovoljno istražen (Eurofound, 2015: 4), iako su top tema koja u posljednje vrijeme zaokuplja pozornost znanstvene i stručne javnosti.

\section{Podjela i obilježja novih oblika rada}

Kao temelj za analizu koristi se jedna Eurofoundova podjela koja uzima u obzir one oblike zapošljavanja koji ulaze u jednu ili više od sljedećih kategorija: odnosi između radnika i poslodavaca koji se razlikuju od prihvaćenih jedan-na-jedan (jedan poslodavac - jedan radnik) odnosa zaposlenja; obavljanje rada koje nije kontinuirano ili je povremeno i traje vrlo kratko (u odnosu na ono koje je stalno ili redovito); sporazumi koji se temelje na umrežavanju i suradnji između samozaposlenih osoba. Kao mogući kriterij uzima se i: mjesto rada koje nisu prostorije poslodavca, mobilnost radnika te rad kod kojeg se jako ili pretežno koristi ICT. Važno je istaknuti da nije uzeto u obzir je li neki oblik rada uređen odredbama općeg radnog prava ili posebnom regulativom, odnosno kolektivnim ugovorima, te kojom vrstom ugovora ili nije pravno uređen, ali se pojavljuje u praksi. Također, nije relevantna djelatnost ili zanimanje (Eurofound, 2015: 4-5).

Prema Eurofoundu novi oblici rada (zapošljavanja) mogu se klasificirati u devet široko određenih vrsta: dijeljenje posloprimaca (employee sharing); dijeljenje posla (job sharing); privremeni menadžment (interim management); povremeni rad (casual work); ICT mobilni rad (ICT-based mobile work); rad putem vaučera (voucher-based work); portfolio rad (portfolio work); zapošljavanje mnoštva (crowd employment); suradničko zapošljavanje (collaborative employment). Oni se mogu dodatno podijeliti u dvije skupine pa dijeljenje posloprimaca i dijeljenje posla predstavljaju nove vrste radnog odnosa (odnosa zaposlenja, new models of employment relationship) između poslodavca i radnika ili klijenta i radnika koji se razlikuje od tradicionalnog radnog odnosa između jednog poslodavca i jednog radnika, dok ostali navedeni oblici predstavljaju nove načine na koji se rad obavlja (work patterns). Oblici se mogu preklapati, a neki odnos zaposlenja može imati obilježja dviju ili više navedenih kategorija (Eurofound, 2015: 7). Analiza prava, obveza i odgovornosti pojedinih sudionika takvih odnosa te uvjeta rada omogućit će zaključak o izloženosti ovih radnika psihosocijalnim rizicima i stresu na radu.

\section{Dijeljenje posloprimaca}

Kod dijeljenja posloprimaca (employee sharing) radnika zajednički zapošljava skupina poslodavaca kojima trebaju radnici. Svrha je omogućiti radniku radni odnos na neodređeno vrijeme, u kojem će radnik ostvariti puno radno vrijeme kombinacijom rada s nepunim radnim vremenom kod više poslodavaca koji bi inače radniku mogli ponuditi samo nesigurno zaposlenje. $\mathrm{Na}$ taj način ostvaruje se ravnoteža između fleksibilnih potreba poslodavaca za radnicima i težnje radnika za sigurnim radnim odnosom. Razlikuju se dva oblika: strateško i ad hoc dijeljenje posloprimaca. Strateško dijeljenje posloprimaca ima sličnosti $s$ agencijskim radom. Skupina umreženih poslodavaca zapošljava jednog ili više radnika koji obavljaju pojedinačne radne zadatke rotirajući se kod tih poslodavaca. Predstavlja oblik suradničkog upravljanja ljudskim potencijalima, u kojem sudjeluje više poslodavaca, uglavnom malih i srednjih poduzeća iz iste regije kojima trebaju radnici za rad s nepunim radnim vremenom, što ostvaruju zajedničkim osnivanjem pravne osobe koja zapošljava radnike. Svrha je stvoriti „kolektivno osoblje" koje se može uspješno integrirati u kolektive različitih poslodavaca, uz osjećaj pripad- 
nosti i predanosti. Pogodno je za zapošljavanje: sezonskih radnika, u nepunom radnom vremenu, na povremenim poslovima (npr. $u$ industriji ili novim projektima). Neke od temeljnih pretpostavki održive primjene strateškog dijeljenja posloprimaca jesu uzajamno povjerenje svih sudionika; odgovarajuća zemljopisna udaljenost između sjedišta poslodavaca kako bi radnici mogli i željeli putovati na radno mjesto; plaće i uvjeti rada dijeljenih radnika koji su slični onima stalnih radnika poslodavca, u cilju sprečavanja socijalnog dampinga i negativne radne atmosfere.

Kod ad hoc dijeljenja posloprimaca poslodavac šalje radnika čiji mu rad privremeno nije potreban drugom poslodavcu. Riječ je o instrumentu koji ima niz prednosti. Može se koristiti kao alternativa otkazima ugovora o radu odnosno skraćivanju radnog vremena, za sprečavanje podzaposlenosti radnika što ima osobitu važnost u vremenima krize, kod restrukturiranja unutar grupacije poduzeća, programa zbrinjavanja viška radnika i sl. lako se radnik uključuje u organizaciju poslodavca primatelja, ugovor o radu između izvornog poslodavca i radnika ostaje na snazi. Ovdje, također, postoji sličnost s agencijskim radom, s tom razlikom što se izvorni poslodavac ne bavi djelatnošću ustupanja radnika te je riječ o privremenom ustupanju radnika nakon kojega se radnik vraća na rad kod izvornog poslodavca ( $E u$ rofound, 2015: 11d). Prema stajalištu u domaćoj literaturi novi institut ustupanja radnika povezanom poslodavcu, uveden Zakonom o radu (dalje u tekstu: ZR), iz 2014. godine (članak 10.), predstavlja ad hoc dijeljenje posloprimaca (Novaković, 2016: 4; Grgurev i Vukorepa, 2017.). Sličan institut poznat je u mađarskom pravu te se ustupanje može izvoditi zbog ekonomskih razloga, između vlasnički povezanih trgovačkih društava. Treba istaknuti da se $u$ istraživanju Eurofounda izričito navodi da je dijeljenje radnika između poslodavaca koji su vlasnički povezani stariji oblik i regulativa koja nije općeprihvaćena, pa zato ne ulazi u kategoriju ad hoc dijeljenja posloprimaca (Eurofound, 2015: 11). Ipak, ustupanje radnika povezanom poslodavcu prema ZR-u kao novi oblik privremenog zapošljavanja kod drugog poslodavca ulazi u kategoriju "trostranih radnih odnosa" pa zaslužuje posebnu pozornost, osobito s obzirom na činjenicu da su zbog nejasne odredbe uvjeti rada odnosno status takvih radnika obilježeni nesigurnošću.

Kad je riječ o uvjetima rada radnika, kod strateškog dijeljenja posloprimaca radniku je poslodavac grupa poslodavaca, posebna pravna osoba. Ona brine o ljudskim potencijalima, uvođenju radnika u rad i njihovom usavršavanju, određuje uvjete dijeljenja posloprimaca, kodekse ponašanja, prava i obveze poslodavaca i radnika te uvjete za moguće zapošljavanje dijeljenog posloprimca kao stalnog radnika nekog poslodavca. Važno je da za organizaciju rada, čiji je dio i zaštita na radu, solidarno odgovaraju poslodavci kod kojih radnik obavlja rad. Najpoznatiji zakonom uređeni model strateškog dijeljenja posloprimaca razvila je Francuska. Primjenjuje se u svim sektorima, a radnicima je zajamčeno jednako postupanje kao i stalnim radnicima poslodavaca u vezi s plaćom i sudjelovanjem u dobiti. Da uvjeti rada dijeljenih posloprimaca mogu biti dobro uređeni, što će posljedično utjecati i na upravljanje psihosocijalnim rizicima, može ilustrirati primjer iz Njemačke. Savezna udruga njemačkih grupa poslodavaca donijela je u suradnji s regionalnim subjektima (među ostalim i sindikatima) poseban kodeks ponašanja za strateško dijeljenje posloprimaca koji sadrži standarde kvalitete. Njegov najveći nedostatak je što nije obvezujući. Mogu se izdvojiti sljedeća pravila. Ugovor o radu temelji se na načelima solidarnosti i podijeljene odgovornosti poslodavaca - članova grupe. Njime se obvezno uređuje radno vrijeme i shema rada, trajanje razdoblja rada kod pojedinog poslodavca, pravo radnika na otkazni rok prije prelaska na rad kod drugog poslodavca, zemljopisna udaljenost među poslodavcima, sadržaj i vrsta zadataka, uvođenje u rad i usavršavanje. Poslodavci se obvezuju primijeniti pravilo o jednakoj plaći i jednakom postupanju prema dijeljenom posloprimcu u odnosu na svoje stalne radnike. Posebna briga posvećena je razvoju kompetencija radnika pa je potrebno donijeti godišnji plan usavršavanja, a posebno se uređuje financiranje i provođenje uvođenja u rad i usavršavanja (formalnog i neformalnog) radnika. Poslodavci su obvezni uključiti dijeljene posloprimce u sve relevantne aktivnosti, uključujući odlučivanje o uvjetima rada, zaštiti na radu i usavršavanju (Hartmann, Meyer-Wölfing, 2012.). Važno je istaknuti da postoji veliki raskorak između ovdje 
propisanih minimalnih standarda i prakse. Zbog nepostojanja posebne regulative grupa poslodavaca organizirana je kao agencija za privremeno zapošljavanje, što uzrokuje probleme u vezi $s$ uvjetima rada dijeljenih posloprimaca kao agencijskih radnika koji su uobičajeno lošiji nego oni stalnih radnika poslodavca. S obzirom da se na njih primjenjuju kolektivni ugovori ili propisi koji uređuju minimalnu plaću, moguće su i situacije da dijeljeni posloprimci imaju veću plaću nego stalni radnici, što se posljedično odražava na radnu atmosferu. Također, zbog mehanizma „posuđivanja" radnika teže se stvara osjećaj zajedničke odgovornosti i solidarnosti. U Austriji su grupe poslodavaca, također, organizirane kao agencije za privremeno zapošljavanje što stvara slične probleme. Ako su odredbe kolektivnog ugovora koji obvezuje poslodavca povoljnije od kolektivnog ugovora agencije za privremeno zapošljavanje, dijeljenim posloprimcima mora se jamčiti jednaka plaća, radno vrijeme i pravo na praznike kao i stalnim radnicima (Eurofound, 2015: 19).

Uvjeti rada dijeljenih posloprimaca općenito se smatraju povoljnima (Eurofound, 2015: 129). Ključna pretpostavka za to jest primjena načela jednakog postupanja kao prema stalnim radnicima poslodavca jamstvom jednakih uvjeta rada, jednake plaće i razine socijalne sigurnosti. To može biti uređeno zakonodavstvom, ali i kolektivnim ugovorima te kodeksima ponašanja. Zbog rotacije između različitih poslodavaca ova skupina radnika slabije je uključena u organizacijsku strukturu poslodavca, slabo informirana, a posebice su njihovi interesi nedostatno zastupljeni djelovanjem sindikata i predstavništva radnika. Zbog potrebe da budu fleksibilni i prilagođavaju se promjenama radnog okruženja te radnog vremena, javlja se problem kako uskladiti posao i privatan život, što može dovesti do pojave stresa na radu. Kako bi se postigla bolja ravnoteža, u jednoj austrijskoj studiji preporučuje se voditi brigu o udaljenosti mjesta rada i doma dijeljenih posloprimaca: do $20 \mathrm{~km}$ ako radnik mijenja mjesto rada dnevno, $45 \mathrm{~km}$ ako to čini tjedno, a 80 km za one koji ga mijenjaju mjesečno. Za jednu njemačku grupu poslodavaca neformalno, interno pravilo preporučuje da udaljenost do mjesta rada za radnika ne bude veća od $50 \mathrm{~km}$ (Eurofound, 2015: 28).

\section{Dijeljenje posla}

Kod dijeljenja posla poslodavac zapošljava dva ili više radnika s nepunim radnim vremenom zbog zajedničkog obavljanja poslova u sklopu nekog radnog mjesta, a za čije je izvršenje potrebno puno radno vrijeme. Riječ je o vrsti rada s nepunim radnim vremenom, čija je svrha osigurati stalne radnike koji će obavljati rad. Treba ga razlikovati od skraćivanja radnog vremena (work sharing) kada se radno vrijeme, privremeno i kratkotrajno, ograničava kako bi se rad podijelio između radnika, često zbog izbjegavanja otkaza višku radnika. Postoje brojne razlike u obilježjima dijeljenja posla u pojedinim državama članicama EU-a. Tako se ova vrsta radnog odnosa može temeljiti na ugovoru o radu sklopljenom između pojedinog radnika i poslodavca, ali i na jednom ugovoru o radu između poslodavca i dva ili više radnika koji dijele posao. Dijeljenje posla može se, s jedne strane, smatrati radom s nepunim radnim vremenom koje je uređeno općim radnim zakonodavstvom te se temeljiti na neformalnom sporazumu poslodavca i radnika o uvjetima rada (raspored rada, udio radnog vremena pojedinog radnika, načini zamjene radnika i slično), kao što je to primjerice u Poljskoj i Češkoj. S druge strane, u nekim zakonodavstvima uređeno je kao poseban institut, različit od rada s nepunim radnim vremenom (npr. u Italiji, Mađarskoj, Ujedinjenom Kraljevstvu, Slovačkoj). Važno je istaknuti da se obveza odnosno način zamjene odsutnog radnika najčešće uređuje zakonom, dok se ugovorom o radu odnosno kolektivnim ugovorom uređuje plaća, pravo na odmore, dopuste i slično (Eurofound, 2015: 31d). Kao posebnost izdvaja se slovenski model dijeljenja posla koji ustvari predstavlja novu mjeru aktivne politike tržišta rada. Riječ je o mjeri uvedenoj 2011. godine člankom 31. Zakona o uređivanju tržišta rada $(U L, b r .80 / 10,21 / 13$, 63/13, 100/13; ZUTD). Suština ove mjere je da radnika koji pohađa obrazovanje na koje ga je uputio poslodavac te zbog toga radi u skraćenom radnom vremenu zamjenjuje nezaposlena osoba čiji rad subvencionira država. Cilj koji se mjerom želi postići jest unaprijediti znanja i sposobnosti već zaposlenih radnika te posljedično povećati konkurentnost poduzeća te, s druge strane, omogućiti nezaposlenim osobama stjecanje praktičnih znanja i iskustva i time smanjiti nezaposlenost. 
Inače, dijeljenje posla u slovenskom radnom zakonodavstvu nije posebno uređeno, niti se često koristi u Sloveniji jer poslodavac za dva radnika koji obavljaju rad s nepunim radnim vremenom ima veće troškove, nego u slučaju kada bi rad obavljao jedan radnik u punom radnom vremenu (prije svega zbog troškova prijevoza i prehrane). Rad s kraćim radnim vremenom (pa tako i dijeljenje posla) čest je kada je riječ o radnicima koji imaju pravo raditi kraće u skladu s posebnim zakonima, zbog invalidnosti, zdravstvenih razloga ili korištenja prava u vezi s roditeljstvom (Senčur Peček, 2005: 1667). Općenito, istraživanje pokazuje da poslodavci ovaj oblik zapošljavanja koriste kako bi svojim radnicima omogućili fleksibilniji način obavljanja rada, zadržali kvalificirane radnike, podigli svoj ugled i brendirali se, osigurali neometano obavljanje posla. U nekim slučajevima zakonodavstvo propisuje obvezu zapošljavanja određenih skupina osoba u fleksibilnom, nepunom radnom vremenu, primjerice osoba $s$ invaliditetom, radnica nakon korištenja rodiljnog dopusta i sl. Radnike privlači ovakav fleksibilni oblik rada jer omogućava usklađivanje posla i obiteljskih obveza, daljnje obrazovanje i napredovanje u karijeri (pa čak i sprečavanje obolijevanja zbog rada s punim radnim vremenom). Oni najčešće i daju inicijativu za ovakvo zapošljavanje. Prednost je i mogućnost učenja te razmjene iskustva i znanja među radnicima na dijeljenom radnom mjestu. Nedostatak je gubitak nekih prednosti u vezi s radom s punim radnim vremenom, mogući sukob među radnicima i nemogućnost kontrole nad rezultatima rada. Na temelju analize može se zaključiti da sigurnost zaposlenja odnosno radnog mjesta ovih radnika ovisi o razlikama u uređenju prava i obveza u zakonu, kolektivnom ugovoru i/ili pojedinačnom ugovoru o radu. Kada je riječ o zaštiti sigurnosti i zdravlja na radu, čini se da uživaju jednaku razinu zaštite i prava kao i drugi radnici koji rade s nepunim radnim vremenom (Eurofound, 2015: 37d).

Kod dijeljenja posla važno je pažljivo izabrati radnike odgovarajućih kvalifikacija i sposobnosti te kompatibilnih osobnosti kako bi mogli stvoriti prijateljski, suradnički odnos u cilju nesmetanog obavljanja rada. Podjela zadataka može se također izvršiti na različite načine: podjelom radnog vremena (i ovo u različitim omjerima ili razdo- bljima) u kojima se obavljaju isti zadaci ili pojedinih zadataka, što pretpostavlja komplementarne sposobnosti radnika. Posebnu pozornost valja posvetiti pravilnoj organizaciji rada jer u protivnom može doći do povećanja intenziteta posla, potrebe prekovremenog rada i stresa na radu i u vezi s radom. Stres može imati i emocionalnu dimenziju ako jedan od radnika ne uspije izvršiti svoj zadatak, pa njegov dio posla moraju odraditi ostali radnici, što kod njega izaziva nelagodu, a kod drugih radnika prevelike napore. Jedan primjer iz prakse jest slučaj radnika s invaliditetom zaposlenih u Sveučilišnom medicinskom centru u Ljubljani koji trpe stres na radu jer smatraju da predstavljaju teret za svoje kolege. Zato se trude raditi više no što se od njih očekuje i no što stvarno mogu. Pod stresom su ne samo zato što više rade, nego i zato što su ostali radni kolege zbog njih preopterećeni. Često ne mogu izvršiti sve zadatke koji su im povjereni, ali ne žele od toga odustati (Eurofound, 2015: 38).

\section{Povremeni rad kao jedan od novih načina obavljanja rada}

Povremeni rad (casual work) takva je vrsta fleksibilnog, neredovitog ili privremenog rada kod kojega poslodavac nije obvezan radniku redovito davati posao, već ga može pozvati po potrebi. Čest je u djelatnostima sa sezonskim karakterom rada ili promjenjivom potrebom za radnicima, kao što su turizam, poljoprivreda, ugostiteljstvo i medicinska skrb kod kuće. Razlikuju se privremeni rad (intermittent work) i rad po pozivu (on-call work). Kod privremenog rada poslodavac od radnika traži obavljanje nekog zadatka redovito ili neredovito, često u vezi s određenim projektom ili sezonskim poslovima. Radnika se zapošljava na određeno vrijeme. Rad po pozivu radnik obavlja u sklopu stalnog radnog odnosa, a specifičnost je da mu poslodavac ne mora kontinuirano davati posao, već samo ako ga zatreba. $U$ ugovoru o radu naznačuje se minimalan i maksimalan broj radnih sati, no postoje i ugovori na nula sati (zero-hours contracts) kod kojih nije određen minimalan broj sati rada, pa poslodavac ne mora uopće pozvati radnika da radi. Ovaj oblik rada doživio je svoj procvat posljednjih desetak godina $u$ nekim državama (Irska, Italija, Nizozemska, Švedska, UK). 
Rad po pozivu i rad na nula sati poslodavcima pružaju ad hoc fleksibilnost u zadovoljavanju potreba za radnicima, a radnicima fleksibilnost radnog vremena, mogućnost usklađivanja obiteljskih i poslovnih obveza, ali i lakši pristup tržištu rada (ILO, 2004.). Za neke znači dodatnu zaradu, mogućnost unapređenja profesionalnih sposobnosti i stjecanja iskustva, kao i korak prema standardnom radnom odnosu. No, zbog opasnosti od prevelike fleksibilizacije na teret radnika u zemljama u kojima se intenzivno koristi vidljiv je trend strože regulative kojom se nastoje zaštititi radnici i dati im nužnu sigurnost, a s druge strane zadržati potrebnu razinu fleksibilnosti za poslodavce. Pitanja koja se javljaju kod ove vrste rada jesu: ograničenje sklapanja ugovora (broj uzastopnih ugovora, zabrana u nekim sektorima), obveza radnika da prihvati ponuđeni rad, zaštita materijalnih prava radnika, pretvaranje ugovora o radu na određeno vrijeme u ugovore na neodređeno vrijeme i druga.

Povremeni rad često se povezuje s eksploatacijom radnika i mogućim zloporabama od strane poslodavca. Uvjeti rada mogu biti loši, primjerice, vrlo kratko vrijeme od poziva radnika na rad do efektivnog započinjanja rada ili često penaliziranje radnika koji su odbili rad po pozivu. Poslodavac prema takvom radniku postupa kao prema svojem stalnom radniku u vezi s davanjem uputa, opreme i nadzora nad radom. O jakom elementu fleksibilnosti govori i naziv "dnevni radnici" za radnike koji takav rad obavljaju u Rumunjskoj koja, također, ograničava sektore u kojima je dopušten. U Francuskoj posebne ugovore na kratko vrijeme imaju radnici u industriji zabave koji se smatraju povremenim radnicima. Za istaknuti je da uživaju neke pogodnosti, pa oni koji su bili zaposleni četiri mjeseca imaju pravo na osmomjesečnu naknadu za nezaposlenost, kao neku vrstu kompenzacije za sezonski karakter rada. Navedeni modeli uređeni su zakonom čime se postiže pravna sigurnost takvih radnika i odnosa, a s druge strane želi spriječiti rad na crno (Eurofound, 2015: 53-54).

$U$ hrvatskom pravu povremeni rad je rad za stalne sezonske poslove (čl. 16. ZR-a) te dodatni rad do najdulje 180 sati godišnje (čl. 62. ZR-a) kao i rad umirovljenika (prema Zakonu o mirovinskom osiguranju). U Sloveniji umirovljenici, također, mogu obavljati povremeni ili privremeni rad u skladu s odredbama ZUTD (čl. 27.a do 27.g.). lako nije riječ o radnom odnosu, na njih se primjenjuju odredbe Zakona o radnim odnosima (UL, br. 42/2012; ZDR-1) o zabrani diskriminacije, spolnog i drugog uznemiravanja i zlostavljanja na radnom mjestu, jednakom postupanju s obzirom na spol, o radnom vremenu, odmorima i dopustima te odgovornosti za štetu, kao i propisi koji uređuju sigurnost i zdravlje na radu. ZUTD određuje i minimalnu plaću po satu koja iznosi 4,20 eura. Za sporove između poslodavca i izvršitelja nadležan je radni sud. Takav rad ograničen je na najdulje 60 sati u kalendarskom mjesecu, a prihod izvršitelja ne smije prijeći 6.300 eura u jednoj kalendarskoj godini. Ograničenja na strani poslodavca povezana su s brojem zaposlenih radnika, pa će poslodavac koji zapošljava veći broj radnika moći imati i veći broj sati povremenog ili privremenog rada (od 60 sati mjesečno u slučaju ako poslodavac nema niti jednog zaposlenog radnika, do 1.050 sati ako zapošljava više od 100 radnika); (Senčur Peček, 2013: 932, 933).

U Sloveniji se rad koji studenti i učenici srednjih škola obavljaju na temelju ugovora o djelu smatra povremenim odnosno privremenim radom. Uređen je Zakonom o zapošljavanju i osiguranju za slučaj nezaposlenosti (UL, br. 107/2006 (ZZZPB UPB1). Ovaj oblik rada bio je ranije iznimno popularan zbog financijske konkurentnosti (manjih tereta davanja i doprinosa), elastičnosti (posredovanje rada putem uputnica), ali i zato što studentski rad nije vremenski ni sadržajno ograničen (Senčur Peček, 2013: 933). Danas je za studentski rad određena minimalna bruto satnica (4,53 eura), a studenti i učenici koji rad obavljaju uključeni su u obvezno mirovinsko i invalidsko osiguranje (što znači i obvezu uplate doprinosa). Sve to utječe na popularnost studentskog rada koji je još uvijek vrlo raširen. lako nije riječ o radnom odnosu, na rad studenata primjenjuju se odredbe ZDR-1 o zabrani diskriminacije, jednakom postupanju bez obzira na spol, o radnom vremenu, odmorima i dopustima, posebnoj zaštiti posloprimaca mlađih od 18 godina i odgovornosti za štetu, kao i regulativa o sigurnosti i zaštiti na radnom mjestu. lako se studentski rad smatra povremenim i privremenim radom što je i bila njegova svrha, često se koristi kao oblik redovitog, trajnog obav- 
ljanja rada na sistematiziranim radnim mjestima. S obzirom da postoje slučajevi u kojima studentski rad ima elemente radnog odnosa, bilo je i sudskih postupaka u kojima su studenti uspješno dokazali da su ustvari "posloprimci“" (Senčur Peček, 2017.). Sličan problem česte prakse korištenja studentskog rada postoji i u Hrvatskoj. Studenti su jeftina radna snaga. Nije riječ samo o pravnom, nego i važnom političkom pitanju.

Kao što je istaknuto, povremeni rad donosi visoku razinu fleksibilnosti za poslodavce, a nisku razinu sigurnosti za radnike. Rad traje ograničeno, kratko vrijeme što utječe na visinu i sigurnost plaće i socijalne zaštite te uzrokuje nezadovoljstvo radnika. Radno vrijeme je teško predvidjeti pa se radnici, kako pokazuju istraživanja, često osjećaju očajni i izrabljivani. Radnici na poziv imaju manje autonomije i pred njih se stavljaju manji zahtjevi u vezi s poslom (Wagenaar et al., 2012: 764). Općenito, povremeni rad češće obavljaju mlade osobe, niže obrazovani radnici i žene, dakle ranjivije skupine radnika. lako fleksibilnost omogućuje usklađivanje posla i privatnog života, nesigurnost hoće li imati posla može uzrokovati mentalni stres, a nepredvidivost posla i radnog vremena ustvari onemogućiti usklađivanje posla i obiteljskog života pa je riječ o začaranom krugu. Povremeni radnici često prihvaćaju više poslova kako bi izgradili reputaciju osobe koja ne odbija posao. Kako u nekim zakonodavstvima (modelima) nema ograničenja radnog vremena, postoji mogućnost da ono bude predugo što, zbog nedostatnog odmora, utječe negativno na privatni život, ali i zdravlje radnika. Primjer iz Slovačke pokazuje da je povremeni rad gotovo pravilo u djelatnosti zdravstvene zaštite, pa se zaposlenici bolnice koji su u redovitom radnom odnosu s punim radnim vremenom zapošljavaju kao povremeni radnici s nepunim radnim vremenom na istom radnom mjestu kod nekog drugog pružatelja zdravstvenih usluga, što može rezultirati stresom na radu i u vezi s radom (Eurofound, 2015: 66-67). Moguća je usporedba sa slučajem hrvatskih liječnika anesteziologa koji su donedavno vikendom mogli dodatno raditi u nekoj medicinskoj ustanovi u Sloveniji.

Za položaj povremenog radnika od odlučujućeg je značenja primjena načela jednakog postupanja (jednake plaće). Plaća iz povremenog rada ionako predstavlja nestabilni prihod, a ako se ne primjenjuje načelo jednakog postupanja, povremeni radnici ostaju bez određenih dodataka na plaću, npr. stimulativnog dodatka. Često sami snose troškove prijevoza ili troše privatno vrijeme na radne zadatke. Jedan od problema jest $\mathrm{i}$ nedostatno usavršavanje. Važno je pitanje postoji li obveza poslodavca da i na povremene radnike primijeni propise koji uređuju sigurnost i zaštitu zdravlja na radu na jednak način kao na svoje stalne radnike. Mađarski Zakon o pojednostavljenom zapošljavanju obvezuje poslodavca na jednako postupanje, što se odnosi i na zaštitu na radu. Ako propusti utvrditi neki rizik za zdravlje radnika, snosi odgovornost u slučaju nezgode na radu. To se može izbjeći ili ublažiti prethodnim ispitivanjem zapošljivosti radnika, tj. utvrđivanjem kojih se općih ograničenja poslodavac mora držati pri davanju radnih zadataka radniku. Ispitivanje se može obaviti na zahtjev jedne ili druge strane, a u nekim je slučajevima obvezno (npr. za radnice trudnice ili dojilje, mlade radnike); (Eurofound, 2015: 69-70).

\section{Drugi oblici rada}

Izloženost psihosocijalnim rizicima prisutna je i kod drugih oblika organizacije rada. Portfolio rad (portfolio work) je takav oblik rada kod kojeg samozaposlena osoba obavlja manje poslove za veliki broj klijenata, dok kod suradničkog zapošljavanja (collaborative employment) slobodna zanimanja, samozaposlene osobe i mikropoduzeća surađuju kako bi prevladali ograničenja koja im nameće njihova veličina i profesionalna izoliranost. Ovdje valja istaknuti kategoriju samozaposlenih osoba koje ostaju izvan dosega zaštite radnog i socijalnog zakonodavstva. Njihov status je često prekaran, posebice ako je riječ o prikrivenim samozaposlenim osobama. Za razliku od hrvatskog, slovensko pravo jamči ograničenu radnopravnu zaštitu "ekonomski ovisnoj osobi“, tj. osobi koja na temelju ugovora građanskog prava osobno obavlja rad, samostalno i za naknadu, kroz dulje razdoblje, u odnosu ekonomske ovisnosti o naručitelju te ne zapošljava radnike (čl. 213. ZDR1). S druge strane, valja razlikovati „prikrivene samozaposlene" osobe koje su ustvari posloprimci, ali ostaju izvan dosega radnozaštitnog zakonodavstva (Senčur Peček, 2017.). Problem statusa samozaposlenih parasubordiniranih osoba poprima sve ozbiljnije razmjere (Rogowski, 2013: 87d). 
Na koncu, valja spomenuti dva oblika organizacije rada koji brzo rastu. Kod ICT mobilnog rada rad se obavlja s bilo kojeg mjesta, u bilo koje vrijeme, uz korištenje suvremenih tehnologija (mobilne tehnologije i komunikacijskih medija, prije svega, pametnih telefona i tableta, internetske veze). Osnovne karakteristike jesu nepostojanje fiksnog radnog prostora, korištenje interneta, menadžerska podrška mobilnosti i kultura mobilnog rada. S obzirom na to, razlikuju se: potpuna mobilnost, mobilnost na određenom prostoru, radna mjesta na više lokacija i umrežena radna mjesta. "Mobilni radnici", "e-nomadi", mogu biti u radnom odnosu i/ili samozaposlene osobe. Korištenje suvremenih tehnologija nalazi se i kod zapošljavanja mnoštva (crowd employment), u kojem se poslodavci i radnici dovode u vezu korištenjem online platforme, često za obavljanje nekog većeg posla koji se dijeli među radnicima kao "virtualni oblak". Kod mobilnog rada kao poseban problem prepoznato je pitanje izoliranosti, slabije integracije u organizaciju, što uzrokuje nedostatne socijalne kontakte, lošiju neformalnu razmjenu informacija s kolegama, a posljedično i stres na radu (Eurofound, 2015: 77d). Stres na radu osjećaju posebice oni radnici koji su dostupni poslodavcu izvan redovitog radnog vremena (Maschke et al., 2014: 157).

\section{ZAKLJUČAK}

Uvjeti rada atipičnih radnika često su lošiji od onih koje imaju radnici u standardnom radnom odnosu te je samim time posao koji obavljaju za njih stresniji. Za zaštitu od psihosocijalnih rizika i stresa na radu ključan je njihov radnopravni te, posljedično, socijalnopravni položaj. Temeljno pitanje je obavlja li osoba rad na osnovi ugovora o radu jer se u tom slučaju na nju primjenjuje radnozaštitno zakonodavstvo. Ako radi na temelju ugovora o djelu (ili drugog ugovora građanskog prava), moguća je ograničena primjena radnog zakonodavstva, kao što je primjerice u slučaju ekonomski ovisnih osoba u Sloveniji, a ako se ono uopće ne primjenjuje, atipični radnik je u najtežem položaju. Nadalje, važno je da li je određeni oblik rada odnosno organizacija rada uređen zakonodavstvom ili kolektivnim ugovorom kao poseban institut, te detaljnije pojedinačnim ugovorom o radu. Najbolji položaj imaju „radnici“ na koje se, neovisno imaju li ugovor o radu ili drugu vrstu ugovora, primjenjuje načelo jednakog postupanja u pogledu plaće i drugih uvjeta rada kao u odnosu na stalne radnike poslodavca. Tada im se jamči minimalna razina zaštite kao kod standardnog radnog odnosa, što se odnosi i na zaštitu sigurnosti i zdravlja na radu.

Kada je riječ o psihosocijalnim rizicima $i$ stresu na radu kao zasebnom segmentu, Okvirni sporazum kao meko pravo, općenit je instrument koji se odnosi na sve radnike, a zbog neobvezujuće naravi upitna je njegova učinkovitost. lako je kao metoda implementacije najviše zastupljena primjena kroz zakonodavstvo, pokazuje se da su učinkovitiji precizniji, sofisticirani mehanizmi i pravila zaštite (npr. kodeksi ponašanja, posebni alati i standardi), koji će odgovarati karakteristikama pojedine djelatnosti, ili poduzeća/poslodavca, dakle primjena OS-a na razini organizacije (poslodavca). Osobitu ulogu ima kvalitetan socijalni dijalog i kolektivno pregovaranje, ali i menadžment osposobljen za upravljanje psihosocijalnim rizicima i stresom na radu. Može se zaključiti da to ima još veći značaj kod atipičnih oblika rada kod kojih zbog raznovrsnosti oblika posebno učinkoviti mogu biti odgovarajući standardi, kodeksi i dobra praksa, dakle meko pravo.

Hrvatski Zakon o zaštiti na radu sadrži neučinkovitu odredbu o stresu na radu, no opći okvir utvrđen europskom Okvirnom direktivom obvezuje poslodavce da pri izradi procjene opasnosti uzmu u obzir i psihosocijalne rizike i stres na radu. U Sloveniji ZVZD-1 nalaže obvezu poslodavcima da planiraju i provode unapređenje zdravlja na radnom mjestu, što uključuje i mjere za otklanjanje psihosocijalnih rizika. Takve mjere bilo bi prikladno urediti i kolektivnim ugovorima (Senčur Peček, 2014: 37). Zaštita na radu inače nije područje koje je u Hrvatskoj prepušteno socijalnom dijalogu. Zato bi jedan od mogućih scenarija za učinkovito upravljanje psihosocijalnim rizicima i stresom na radu bio ojačati odgovornost poslodavca kroz zakonodavstvo, dakle, propisivanjem sankcija u ZNR-u de lege ferenda. Drugi sudionici, poput inspekcije rada te drugih tijela javne vlasti, trebali bi dobiti šire ovlasti za djelovanje, prije svega preventivno. No, država mora raditi na svojim politikama. Kada je riječ o atipičnom radu, takve je oblike potrebno najprije prepoznati 
te pravno urediti, a primjerenu razinu zaštite zajamčila bi primjena načela jednakog postupanja. Druga mogućnost vidi se u autonomnom uređivanju ovog pitanja. No, pretpostavka je za to unapređenje socijalnog dijaloga, kvalitetnije kolektivno pregovaranje, posebice na razini grane te na razini poslodavaca koji zapošljavaju atipične radnike. Za očekivati je da će poslodavci i sami prepoznati da ulaganje u radnika nije samo trošak.

\section{LITERATURA}

Barrett, B., Sargeant, M.: The Health, Safety and Well-being of Vulnerable Workers. U: Vulnerable Workers (Health, Safety and Well-being (ur. M. Sargeant, M. Giovannone), Routledge, London, New York, 2016., 1-20.

Bilić, A., Laleta, S., Barešić, A.: The challenges of part-time work in the context of flexicurity. $\mathrm{U}$ : New Developments in EU Labour, Equality and Human Rights Law (ur. M. Vinković), Josip Juraj Strossmayer University of Osijek Faculty of Law - Jean Monnet Chair in EU Labour, Equality and Human Rights Law, Osijek, 2015., 63-96.

Bodiroga-Vukobrat, N., Pošćić, A., Martinović, A.: Precarious Times, Precarious Work: Lessons from Flexicurity. U.: Contemporary Developments in International Law, Essays in Honour of Budislav Vukas (ur. R. Wolfrum, M. Seršić, T.M. Šošić), Brill Nijhoff, Leiden, Boston, 2016., 405-430.

Bosch, G.: Towards a New Standard Employment Relationship in Western Europe, British Journal of Industrial Relations, 42, 2004, 4, 617-637. cit. prema, Rogowski, R. Reflexive Labour Law in the World Society, Edward Elgar, Cheltham, Northampton, 2013., str. 101.

Branch, A.: The evolution of the European social dialogue towards greater autonomy: challenges and potential benefits, International Journal of Comparative Law and Industrial Relations, 21, 2005., 2, 321-346. cit. prema Leka et al., An evaluation.

Cox, A., Fletcher, L.: Scoping study for a foresight on new emerging occupational safety and health (OSH) risks and challenges, European Agency for Safety and Health at Work, Luxembourg, 2014.

Cox, T., Griffiths, A.: The assessment of psychosocial hazards at work. U: M.J. Schabracq, J.A.M. Winnubst, \& C.L. Cooper (Eds.),
Handbook of work and health psychology, Wiley, Chichester, 1996., 127- 146., cit. prema EU - OSHA, Research on work related stress, 2002.

Deakin, S.: The Comparative Evolution of the Employment Relationship. U: Boundaries and Frontiers of Labour Law (ur. G. Davidov, B. Langille), Oxford and Portland, Oregon, Hart Publishing, 2006., 89-108.

Ertel, M. et al.: European social dialogue, European journal of industrial relations, 16, 2010., 2, 169-183.

European social partners (ESP): Implementation of the European autonomous framework agreement on work-related stress, Report by the European Social Partners adopted at the Social Dialogue Committee on 18 June 2008, dostupno na: http://www.ueapme.com/IMG/pdf/Stress_Final_Implementation_report_231108.pdf, pristupljeno: 15.12.2016.

Eurofound and EU-OSHA: Psychosocial risks in Europe: Prevalence and strategies for prevention, Publications Office of the European Union, Luxembourg, 2014.

Eurofound: Impact of the crisis on working conditions in Europe, 2013., dostupno na: https:// www.eurofound.europa.eu/sites/default/files/ ef_files/docs/ewco/tn1212025s/tn1212025s.pdf, pristupljeno: 7.1.2017.

Eurofound: Developments in working life in Europe: EurWORK annual review 2014, dostupno na: https://www.eurofound.europa.eu/sites/ default/files/ef_publication/field_ef_document/ ef1631en.pdf, pristupljeno: 15.1.2017.

Eurofound: New forms of employment, 2015., dostupno na: https://www.eurofound.europa.eu/ sites/default/files/ef_publication/field_ef_document/ef1461en.pdf, pristupljeno: 30.5.2016.

European Commission (EC): Strategic Framework on Health and Safety at Work 20142020, $\operatorname{COM}(2014) 32$ final, Brussels, 6.6.2014. dostupno na: http://eur-lex.europa.eu/legal-content/EN/TXT/PDF/?uri=CELEX:52014DC0332, pristupljeno: 27.1.2017.

European Commission (EC): Report on the implementation of the European social partners' Framework Agreement on Work-related Stress (Commission Staff Working Paper), Brussels, 24.2.2011 SEC(2011) 241 final

Goldin, A.: Labour Subordination and the Subjective Weakening of Labour Law. U: Boundaries and Frontiers of Labour Law (ur. G. Davidov, B. 
Langille), Hart Publishing, Oxford and Portland, Oregon, 2006., 109-131.

Grgurev, I., Vukorepa, I.: Flexible and New Forms of Employment in Croatia and their Pension Entitlement Aspects. U: Transnational, European, and National Labour Relations (ur. Sander, G. G. et al.), Springer Verlag, Heidelberg ... [etc.], 2017. (u tisku)

Hartmann, T., Meyer-Wölfing, S.: Arbeitgeberzusammenschlüsse in Deutschland: Umsetzung und Diskussionsstand, Arbeitspapiere 45, Materialien zu Flexicurity, G.I.B., 2012., dostupno na: http://www.gib.nrw.de/service/downloaddatenbank/arbeitgeberzusammenschluesse-in-deutschland-umsetzung-und-diskussionsstand, pristupljeno: 29.1.2017.

lavicoli et al.: Hard and soft law approaches to addressing psychosocial risks in Europe: lessons learned in the development of the Italian approach, Journal of Risk Research, 17, 2014., 7, 855-869.

ILO: Changing Patterns in the World of Work, International Labour Conference, 95th Session 2006, Report I(C), Geneva, 2006.

ILO: Safety and health at work: a vision for sustainable prevention, Twentieth World Congress on Safety and Health at Work 2014, Global Forum for Prevention, 24-27 August, 2014., Frankfurt.

ILO: From precarious work to decent work (Outcome Document to the Workers' Symposium on Policies and Regulations to combat Precarious Employment), 2012., 37-38, dostupno na: http:// www.ilo.org/wcmsp5/groups/public/---ed_dialogue/--- actrav/documents/meetingdocument/ wcms_179787.pdf, pristupljeno: 1.2.2017.

ILO: Protecting Workplace Safety and Health in Difficult Economic Times - The Effect of the Financial Crisis and Economic Recession on Occupational Safety and Health, Geneve, 2013. dostupno na: http://www.ilo.org/wcmsp5/groups/public/-ed_protect/-protrav/-safework/documents/publication/wcms_214163.pdf, pristupljeno: 15.1.2017.

Inšpektorat za delo RS, Psihosocialni dejavniki tveganja na delovnem mestu, dostupno na: http:// www.id.gov.si/si/o_inspektoratu/organizacija_ irsd/inspekcija_nadzora_varnosti_in_zdravja_pri_ delu/nadzor_zdravja_pri_delu/analize_projekti/ psihosocialni_dejavniki_tveganja_na_delovnem_ mestu/, pristupljeno: 27.2.2017
Inšpektorat RS za delo o promociji zdravja na delovnem mestu, dostupno na: http://www. id.gov.si/fileadmin/id.gov.si/pageuploads/Varnost_in_zdravje_pri_delu/VISOKE_TEMPERATURE_-_PROMOCIJA/Promocija_zdravja_na_delovnem_mestu.pdf, pristupljeno: 27.2.2017.

Irastorza et al.: Second European Survey of Enterprises on New and Emerging Risks (ESENER-2), Overview Report: Managing Safety and Health at Work, EU-OSHA, 2016, dostupno na: https:// osha.europa.eu/sites/default/files/ESENER2-Overview_report.pdf, pristupljeno: 10.1.2017

Kanjuo Mrčela, A., Ignjatovič, M.: Psychosocial risks in the workplace in Slovenia, Eurofound, 2012., dostupno na: https://www.eurofound.europa.eu/sites/default/files/ef_publication/field_ef_ document/ef1245en.pdf, pristupljeno: 12.2.2017.

Keller, B., Seifert, H.: Regulierung atypischer Beschäftigungsverhältnisse, WSI-Mitteilungen, 46, 1993., 3, 538-545.

Laleta, S., Bodiroga-Vukobrat, N., Fleksigurnost i (de)regulacija tržišta rada, Zbornik Pravnog fakulteta Sveučilišta u Rijeci, 37, 2016., 1, 33-69.

Laleta, S.: Stres na radu i u vezi s radom - normativno uređenje, 5. Međunarodni stručno-znanstveni skup "Zaštita na radu i zaštita zdravlja", 17.-20. rujan 2014., Zadar, Hrvatska, Veleučilište u Karlovcu, Karlovac, 2014., 734-739.

Laleta, S.: Instrumenti implementacije Okvirnog sporazuma o stresu na radu i u vezi s radom s osvrtom na "atipične" radnike, 6. Međunarodni stručno-znanstveni skup "Zaštita na radu i zaštita zdravlja", 21.-24. rujan 2016., Zadar, Hrvatska, Veleučilište u Karlovcu, Karlovac, 2016., 946952.

Leka et al.: Is psychosocial risk prevention possible? Deconstructing common presumptions, Safety science, 71(A), 2015., 61-67.

Leka et al.: An Evaluation of the Policy Context, (2015a), BioMed Research International, vol. 2015, str. 1-8., dostupno na: http:// dx.doi.org/10.1155/2015/213089, pristupljeno 21.1.2017.

Maschke, M., Nies, G., Vogl, G.: Mobile Arbeit: zwischen Autonomie und Fremdbestimmung, WSI Mitteilungen, 2, 2014., 156-159.

Novaković, N.: Novi modeli fleksibilnih oblika zapošljavanja, Radno pravo, 2016., 6, 3-8. 
Parent-Thirion, A. et al.: Fifth European Working Conditions Survey, Eurofound, Publications Office of the European Union, Luxembourg, 2012.

Potočnjak, Ž.: Novine u hrvatskom radnom zakonodavstvu, Zbornik Susreta pravnika Opatija '14 (ur. J. Barbić, M. Giunio), Hrvatski savez udruga pravnika u gospodarstvu, Zagreb, 2014., 291-349.

Rogowski, R.: Reflexive Labour Law in the World Society, Edward Elgar, Cheltham, Northampton, 2013.

Schiarra, S.: National and European Public Policy: the Goals of Labour Law. U: Boundaries and Frontiers of Labour Law (ur. G. Davidov, B. Langille), Hart Publishing, Oxford and Portland, Oregon, 2006., 245-270.

Senčur Peček, D.: Pogodba o zaposlitvi s krajšim delovnim časom, Podjetje in delo, 2005, 6-7, 1664-1683.

Senčur Peček, D.: Zakonite oblike opravljanja dela, Podjetje in delo, 2013., 6-7, 921-943.

Senčur Peček, D.: Okvirni sporazum o stresu v zvezi z delom. U: Kresal Šoltes, K. et al., Vodnik po sporazumih evropskih socialnih partnerjev $z$ vidika vsebin za kolektivna pogajanja, Inštitut za delo pri Pravni fakulteti Univerze v Ljubljani, Ljubljana, 2014., 25-37.

Senčur Peček, D.: Pojem delavca s primerjalnega in EU vidika, Delavci in delodajalci, 2016., 2-3, 189-216.

Senčur Peček, D.: Forms of Work Performed in The Republic of Slovenia. U: Transnational, European, and National Labour Relations (ur. Sander, G. G. et al.), Springer, Heidelberg ... [etc.], 2017. (u tisku)
Smernice za promocijo zdravja na delovnem mestu (2015), Republika Slovenija, Ministrstvo za zdravje, Direktorat za javno zdravje, http://www. mz.gov.si/fileadmin/mz.gov.si/pageuploads/ javno_zdravje_2015/zdr_na_del_mestu/Smernice_promocija_zdravja_na_delovnem_mestu-marec_2015.pdf

Standing, G.: The Precariat: The New Dangerous Class, Bloomsbury Academic, London, 2011., cit. prema Rogowski, R., Reflexive Labour Law in the World Society.

Stone, K.V.W.: Rethinking Labour Law: Employment Protection for Boundaryless Workers. U: Boundaries and Frontiers of Labour Law (ur. G. Davidov, B. Langille), Hart Publishing, Oxford and Portland, Oregon, 2006., 156-179.

Šokčević, S.: Zakon o zaštiti na radu s komentarima i tumačenjima, TIM press d.o.o., Zagreb, 2014.

Vaughan-Whitehead, D., The European Social Model in times of crisis: An overview. U: The European Social Model in Crisis (Is Europe Losing its Soul?) (ur. Vaughan-Whitehead), E. Elgar, ILO, Cheltenham, Northampton, Geneve, 2015.

Wagenaar, A.F. et al.: Can labour contract differences in health and work-related attitudes be explained by quality of working life and job insecurity?, International Archives of Occupational and Environmental Health, 85, 2012., 763-773.

WHO, PRIMA-EF: Guidance on the European Framework on Psychosocial Risk Management: A Resource for Employers and Worker Representatives. Protecting workers' health series no. 9. Geneva: World Health Organization, Geneva, 2008., dostupno na: http://www.who.int/occupational_ health/publications/PRIMA-EF\%20Guidance_9. pdf?ua $=1$, pristupljeno: 13.2.2017.

\section{ATYPICAL WORK - PROTECTION AGAINST PSYCHOSOCIAL RISKS AND WORK-RELATED STRESS}

SUMMARY: Analysed in the paper are the atypical forms of employment and work organisation, with special accent on the work conditions and the protection of workers from psycho-social risks and work related stress, all in the light of the obligations of the EU member states and European social partners in this field of safety and health at work. The authors provide a comparative legal analysis and submit propositions de lege ferenda.

Key words: atypical work, work-related stress, Frame Agreement, Croatian law, Slovenian law, comparative law

Original scientific paper Received: 2017-03-09 Accepted: 2017-07-03 